And is it likely that I should have quoted Sganarelle's "méthode toute nouvelle" as being applicable to the present state of medicine? Why, surely this is an age of "revivals," and very useful revivals, too: temperature-taking, begun by Sanctorius (still living whon I was a boy) more than 250 years ago, and dereloped later by De Haen and others : cold affusion, practised by Wright and Currie in the last century; "masage," well understood at Brighton in Sir H. Halford's time under the simple name of "rubbing," or as the older oriental shampooing, and once daily indulged in by the western ancients in their baths. The bold Brunonians found again, about thirty years ago, an energetic advocate of their doctrine of stimulation; and, although it would appear that the pendulum of practice' has swang to the opposite extreme of "intemperate abstinence" there are still those with whom overpowering draughts of brandy would seem to be the faroured remedy.

A very worthy good fellow, and a cultured, who joined as a few years since, said to me the other day, "Oh ! the doctors have made no advance since the days of Falstaff. Every ailment now-a-days, according to these gentlemen, is traceable either to syphilis or gout. As 'the iat man' had it long ago, 'pox of this gout!' or a gout of this pox, say I; for the one or the other is playing the rogue with my great toe." He went on, moreover, to intimate that the "waterdoctors" of Shakspeare's time knew early as much about the indications derivable from an examination of the urine as do the physicians of the present day ; quoting him again on the opinion given by one of the craft, that Falstaff"s water was "a very good, healthy water; but, for the party who owed it, he might have more diseases than he knew of." The friend to whom I allude was, I need hardly say, not a doctor, but he had consorted much with them; and he wound up his conversation with me by boldly asserting that, had it not been for what he was pleased to speak of as "old Linacre's obstructionist proceedings" (according to Malone) with regard to urinoscopy, a much earlier knowlege of albuminuria would have been available.

But now to the special object of my letter. Poor Sir Henry has been, for some time peist, sorely exercised by the news which has come down to us, that his old and favourite College is about to be "revolutionised." He tells me that, not content with a very liberally wide and wise extension of the Fellowship ; not content with according to the Members a participation in the enjoyment of the building, with its treasures, etc., the governing body took upon themselves, some years back, the examining and licensing of such General Practitioners as chose to present themselves for qualification. Of all this, Sir Henry has expressed his entire approval, as being in accordance with the prevailing moderate Liberalism of the day, and as being likely (the last named step especially) to work advantageously for the benefit of the Public, of the Profession, and of the College.

But to the "revolutionary" proposition now before the College, to dub with the degree of Doctor every individual member of the newly constituted body of Licentiates, he does as entirely object; and he expresses himself very strongly to that effect. I have urged him to put his objections into the form of anothe: letter to you, being moved to press this course upon him the rather, because I cannot appreciate (nor, indeed, hardly approve) all the arguments he adduces against the step proposed, sufficiently to reproduce them myself; and, moreover, because he is becoming (with all deference $I$ say it) somewhat of a bore upon the subject. To this suzgestion, however, he turns a deaf ear ; declares that never more will he write to or read a medical paper (so that he will not see this), and contents himself with mournful mutterings of Ichabod ! Ichabod !

Of the main objections which he has been constantly putting forward, I make very light. He says that the College has no power to grant degrees, in the first place ; and if the power existed, he asks what degree could it confer on the Licentiates without doing an injustice to some of the Fellows and Members, and to all the numerous Licentiates already created who have no degree? Now, have I not shown at the end of Le Malade Imaginaire, Troisieme Intermede, how easy a matter it was to create a Doctor of Medicine in my time; and surely the College of Physicians might do well to adopt the course pursued in the case of Monsieur Argan; it would be but another "revival."

And for the solution of Sir Henry's second difficulty, as to what degree could be conferred without doing an injustice to the existing Fellows, Members, and Licentiates, I would propose that any new candidate, having passed "examinations equal to those required by of the Universities for Degrees in Medicine and Surgery" (the inow proposed), and having heard the judgment,

"Bene, bene, bene, bene respondere,

In nostro docto corpore," might be styled, for exampla, John Smith, I.A.M.M. D., that in, In Arte Mediotidediocriten Doctoss (after the fashion of the Fellows. of All Souts, Oxford, In Anie M(usiod), a quelifieation which he himself woutd, of tebufes be able to read John Smith, I am M.D.-Yours faithfedly,

MoLIkRE.

P.8.- - have just now been told, by a sporting acquaintance, that my proposition is ridiculous! The "discerning public," he says, would assuredly exalt the more largely lettered man; and "the betting" (to ase his own language) "would be exactly 5.to. 2 upon John 8nith for the Popitlaris 'Aura/Stakes." Haw difficult it is to please everyone !

\section{MEMBERS OF THE ROYAL COLLEGE OF SURGEONS.}

Sir, -The annual meeting of the Council, Members, and Fellows of the Royal College of Surgeons is drawing near; and momentous are the issues at stake; it is, therefore, full time that all members of our College should review their position, past and present, and buckle on their armour for the fight. It is no imaginary evil of which they complain, for they have long:been left ont in the cold; their only privilege being the permission to use, at hours inconvenient to busy men, their own library and museum, when not used for other purposes It is almost inconceivable that so large a body of men should 80 long have patiently put up with this treatment; but there are now signs of an awakening, and, as a member of the Association of Members of the Royal College of Surgeons, I may state that letters from all parts of the kingdom are pouring in upan us, expressing the determination of the Members to assert their equitable rights; aye, and to get them.

The demand of enfranohisement has been stigmatised, by some of those interested in its refusal, as democratic; but the allegation will not for one moment hold water, as the appeal is that of men who have a distinct stake in the government of the corporation. To be truly classed as democratic, it would have to be extended to the general body of medical students, or, at any rate, to those who have just so far identified themselves with the College as is implied by the passing of the primary examination. This no rational being would dream of asking, and this has not been asked. What we Members demand is, the recognition of our right to share with the Fellows in the election of members of the Council. This is pressed in no spirit of opposition to, or jealousy of, the Fellows, large numbers of whom have admitted the justice of our claims. But there are questions, prominent among which is that of the professional education of the medical practitioner, which bear far more intimately upon the interests of the Members than they do upon those of that corps d'elite, the Fellows ; and upon these questions it is only just that the Members should, by the mouths of their representatives, have an opportunity of expressing their views.

To presuppose that the Members would be hasty and unintelligent in the choice of their mouthpiece is an unwarrantable hypothesis. Look at them in their ordinary business-life; they have their own way to make in the world, and at every step in their daily path are beset with problems quite as difficult to solve as those presented to the distinguished Fellow whose hospital-appointments will always cast sufficient lustre upon his name for his less prominent brethren, the Members, to send him a never-ceasing stream of clients, each armed with the golden tokens of esteem so sparingly and uncertainly doled out to the family-doctor. A few mistakes in diagnosis are easily overlooked by the generosity and charity of the general practitioner, who judges the consultant by the rule, and not by the exception. Not so with the average Member; he has no brilliant reputation behind which to shelter himself; and often one blunder on his part will, in the eyes of his unreasoning and unstable body of patients, undermine the structure of a practice it has taken him years to rear. For this reason, we say that the Member of the College is a man whose very position as the familiar adviser requires the employment of a vast amount of judgment and discretion; and what he is in the habit of exercising all day long, there is little danger of his discarding when the business on hand is that of electing a Member to represent him on the Council of that College whose name he holds it an honour to bear, even though she conducts herself as though ashamed of her offspring.

Only by the voice of the members and licentiates of the English Colleges being heard in their Councils, can true medical reform be attained, the social relations of the profession with the laity advanced, and the abuses of these close corporations swept away. Therefore, let all who, with their' diplomas, have earned the right to bear the significant title of "Members," muster in force upon the 29 th instant, and show the Council that they are in earpest. 
One wotd mote, end that for the ear of the Coundily it is nbt byien yet too late for it, unoompelled, to grant the inovithble: 1Let it

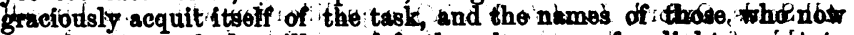
form its august body will stamd forth as beacons of enlightehudeat: to future generations of the followers of Asculapius.-Your obddient servant;

A. Mhay fati

\section{NAVAL AND MILITARY MEDICAL SERVICES.}

THE EGYPTIAN CAMPAIGN.

SIR, - With reference to the letter from "Soudan" in your issue of October 10th,

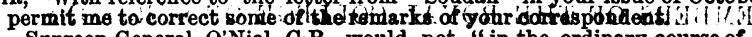

Surgeop-General $Q$ 'Nial, $C_{f} B_{\text {. }}$, Tould not "in the ordinary counse of events, hate becone "entitied in $\mathrm{a}$ few thonths " to his promotion to surgeon-gepderal.

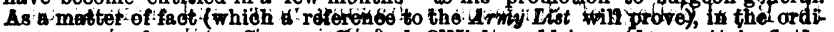

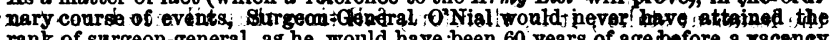
fank of gurgon-gengral as he would haye beep 60 ygars of agebefore a racaney

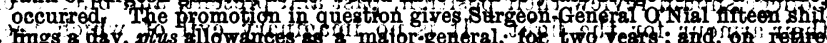

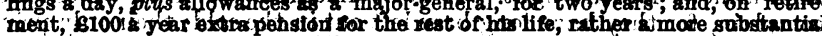
neyrard than being mede on $\mathrm{F}_{\mathrm{C}} \mathrm{B}_{\mathrm{B}}$

It is quite well upderstood that the late surgequ-General Harpott would wa

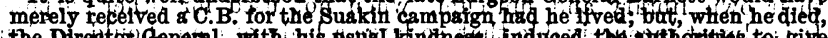

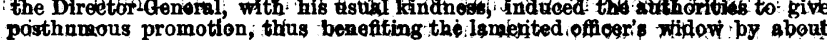
posthnweous promotion; th

"Soudan" draws comparisons between Sir James Hanbpry and" surgeon"" "Soudan" draws comparisons between sir James Hanbpry an' "Surgegn-

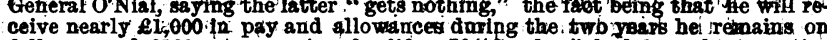

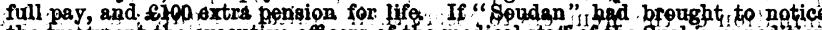
the treatment the executive officers of the medical staff of the Suakin expodition had received at the hands of the authorities in such matters, he would haye inseveral of them hate, in addition, suffered seterely by the promotion of soph of their juniors over their heads. The work at Suakin Was infinitely harder an more dangerous than that of many who went tap the Nhe in adaition to which

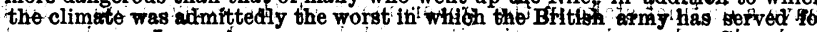
many years.-I am, etc.,

Stbxinfs:!

* * According to the War Office Army Eist; Surgeon-General ON Nikl will not attain the age necessitating retirement intil June 14 tht; 1887. . His ponomotionto surgeon-general's rank bears date June 18th; 1885, and at: that time there were two deputy surgeons-generial only above him in the list of the medical staff. When the uncertainty which attends all matters of the kind is oonsideted, there gre evidently no suffiefent grounds for asserting that Dr. O'Nial, if he had not been promoted for special service in Egypt, either, whonld, or would not, have attained surgeon-general's rank in the course of the two years prior to the date when his enforced retirement from the service, on accoint of the official limit of age, will arrive.

REWARDS IN THE'SOUDAN CAMPAIGN

Wri, - I see in the Journal of Octobier 3rd a short article on the distribution of rewands to the medical officers in the late campaign. Might $I$ ask you to : say a few words for the naval surgeons employed in the Soudan?

AtSuakin, with the marine and naval brigade, two staff-surgeons and four surgeons were employed, some of them for considerably over twelye months.

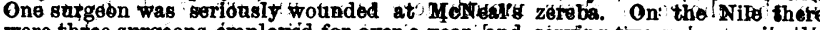
were three surgeons employed for over a year; apd serving tiwo subumens in the Soudan. One of them was present in Lord Chanles Beresford's stogmer action.
Notwithstanding the fact that more than one tiame was submitted to the authoriNotwithstanding the fact that more than one hame was submitted tothe auth or
ties in the official dispatches, not a single reward, or even word bf recoghition, is given to one of these officers:- Yours, etc.,

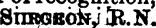

P.S. - In the executive line, for the same services the following hqpours and promations have been made : two captains made $C_{\text {, }}$., two commanders promoted to captain, seven lieutenants promoted to commander, all the sub-lieutenants promoted to lieutenant, one boatiowatic made chiles bootswain; and one chief engineer made an inspector of machinery.

NAVAL MEDICAU SERVIOE.

SIR, - I would thank any of the readers of gour. JOERNAL to answer the following guestiong

First, What is the nature of instruction received in Hasidr todspttal by probationers, atid how dóes it compare with the atray training in wetfiey ?

Secondly; is it a fact that; on one or t two occastions, the newly! passed surgeons have been sent direct to gynnery-ships instead of proceeding first to fraslar?

Thirdly, does the Admiralty allow the same amotunt for expenses of teaching etc. per man when at Hasiar; as the Wor Dejpartmen't allows for atmy surgeons when in Netley?

Fourthly; how does the rank of army and nary surgeons compare upon entering?

Fifthly, why is the navy so unpoptilar as compared with the gister service? By publishing this list of questions you will greatly oblige $A$ Mthersk.

\section{THE NAVY.}

THE following appointments haye been made at the Admiralty during the past week J Jrramar SUGROE, M.D., Surgeon, to the Raleigh; $F$. H. JuLXAN; Sur Crowlink

\section{ARMT MEDICAE CERVIQR.}

SURGEON-MAJOR JOSEPH FLEMTNG; M.D. has retlred on tomporefy half-pay. He

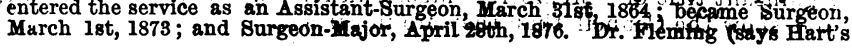

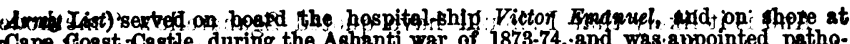
Gape Gost Caste during the Ashanti war of 1873-74; and was appointed patho-

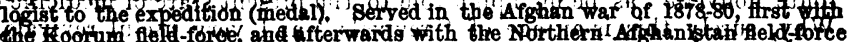
(modieil):

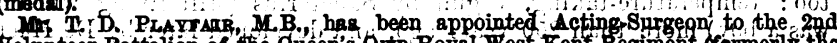

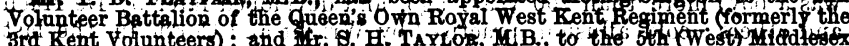

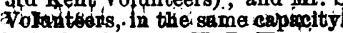

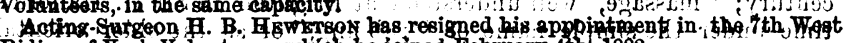

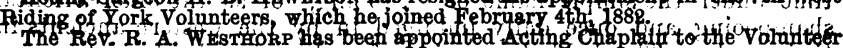
Méaicallstbri Coring

i. The undermenticiod officers of the Medical Staff, orying in the Madras Gom-

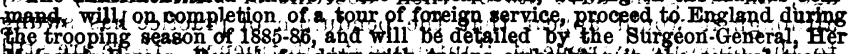

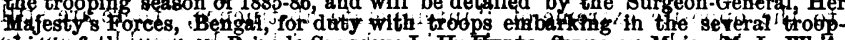

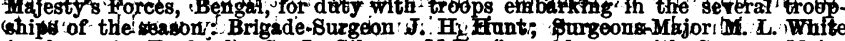

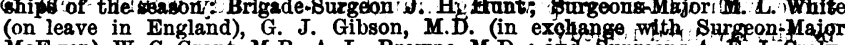

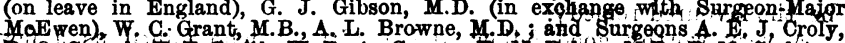

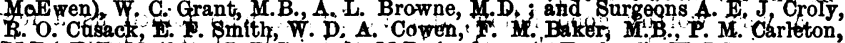

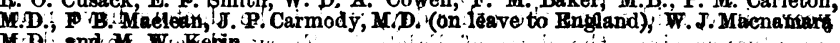
M.Dis, and a

The undarmentioned offers, servipg in the Bomber Presidency, whose tour of

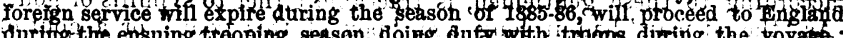
durithy the ensuing trooping season; doing duty with trobps during the voyats:

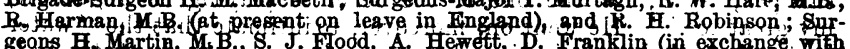

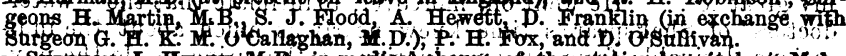

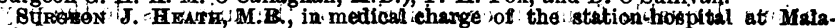
poram Madras Presidency, is directed to do duty at the station-hospital at Segunderabad.

Surgeon R. O. Cusack, doing duty at the station-hospltal at Cannanore, Madras Presidency, is ordered to take medietl charge of the station-hbspital at Mila. puram:

Stargeon R. F. CumMng died at Richmond Barracks, Dablip on October 16th, to his thirty-frst year: Mr.'Cumming entered the service, March 6th, 1880 , and Was appoitted Surgedn to the 2od Battalion of the Bcots Guards, January 12th, 1881. In the summer of 1882, he was transferred to the lst Battalion, and hemaingd with it wh te the'time of his decease. The Armor. Iists do not asign
him any war service, although, we believe, he accompanied his battalion to Egypt in 1882

\section{INDIAN MIDICAL SERVIGE}

SURGEON J C. FULLERTON, Bengal Establishment, officiating Medical oficer of the Beloochistan Agency, is contrmed in that appointinent, vice. Surgeon-Major O. Tuke, M. B., who has resigned

The services of Dr. R. M. MEIKLiesons, an uncovenanted Medical Ofltcer in the Centrat Provinces, are dispensed with from the dato of the receipt, by him, of these ofders.

The services of Burtedn-Major O. T. Doks, M.B.; Bengal Establishment, offciating Joint Medical Offloer at Simla, are, at his own request, placed at the disposal of the Military Department.

The services of Sargeon W.A. QUAYLE, M.D., Madras Establishment, are permanently placed at the disposal of the Chief Commissioner of the Central Provinces.

Surgeon G. F. A. HAaris, Bengal Fstablishment, is directed to officiate as Joint Medical Officer at Bimla, in succession to Surgeon-Major $\mathbf{Q}: \mathbf{T}$. Duke, during the bsence, on furlough, of Surgeon-Mdjor $\mathbf{R}$. Power, or till further orders.

In modiffcation of the orders of July 9th, Surgeon-Major $J_{2} \mathbf{F} . \mathbf{P}_{\text {. }} \mathbf{M}^{\mathrm{C}}$ CoNiseL,

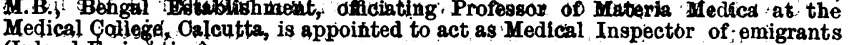
(Inland Ampigration)

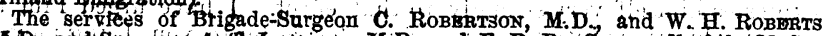
M.D.; ad Surgeons A. T. L. KATOH, M.B., and E. R. DA OostA, all of the Madras Establishment, are placod at the disposal of the Provincial Commander-in-Chief. Surgeon-Major $\mathrm{r}_{\mathrm{j}}$ J. SMITH, Madras Establishment, in joint medical charge at Ootacanund, is appointed to the medical charge of the army headquarters and establishment, in additton to his other. daties.

Surgeon J. P. GREst Y, M.D, Bombay Kistablishment, hasi been permitted by the Secretary of State for India to return to dutz

Surgeon-Major H. B. Purves, Bengal Establishment, Civil Surgeon of the 24th Pergunnahs,

Surgeon-Major G. R. DaphtaRY, Bengal Establishment, on return from furlough, is posted as Civil Surgeon to the Betul District.

\section{MEDICO-LEGAL AND MEDICO-ETHICAL,}

\section{VACCINATION:}

Sir,-A. vacainates a child in three places; only one takes A. Wishes to revaccinate the infant from the tesicle in two other places'; the friends refase to

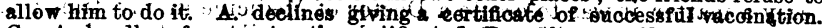
Can As legally refuse to sign the certificate ? Does the revaéciration from the original resicle'mgke the child more, secure? The parents have been informed
it does not, and that the baby would be subjected to unnecessary pain.-I am, etc.,

*** A. cannot legally refuse to sign. The vaceination, though medically an imperfeci one, is; legally, a complefed operation. Stectesful vaccination in two more places, whether by lymph taken' from the firit' wesicle, or by other Iynth wonld inniuestiotiably have giten to the child greater security against smallpox, did suctess would have been made mbire likely if the operationibad been carried out as A. puoped in Under the circumstances, it would now better to leave any further attempt at securing a more protective vaccination until the child is five years old, unless, indeod, it should bo specially exposed to smallpox before that date. 